\title{
VINO AMARO NAŠEG DRUŠTVENOG SUSTAVA - POSLJEDICE ODGOJNO-OBRAZOVNE I ZNANSTVENE POLITIKE
}

\begin{abstract}
Osnovna zadaća našeg društvenog sustava ogleda se u osuvremenjivanju obrazovnog i školskog sustava. No pitanje je koliko je taj zadatak aktualiziran s obzirom na niz poteškoća - objektivnih i subjektivnih. Znanje, kao finalni rezultat odgojno-obrazovnog procesa, uključuje stjecanje kompetencija, postignuće ishoda, koji zajedno čine pretpostavku kvalitetnog obrazovnog sustava na svim razinama. Ovdje se posebno razmatra pitanje kvalitete visokog obrazovanja i njegova daljnjeg prosperiteta poštujući pritom psihološke standarde kompetencija ličnosti te nužne pedagoško-psihološke i didaktičko-metodičke edukativne procese. Sve to objedinjeno čini kvalitetan društveni standard kojim se bave i Өdgøjn Europska unija i Europski parlament. Pitanje cjelovite vertikale obrazovnog sustava finalizira se cjeloživotnim učenjem, koje ima najdirektnije veze s gospodarstvom. Tako sve rečeno čini pitanje nacionalne odgovornosti s posebnim naglaskom stavljenim na visokoškolsko obrazovanje i rezultate koji iz njega proizlaze.

Ključne riječi: cjeloživotno obrazovanje; društveni standardi; komunikacijska psihologija; nacionalna odgovornost;odgojno-obrazovni proces, pedagoško-psihološke i didaktičko-metodičke kompetencije; psihološki standardi kompetencija ličnosti; visokoškolsko obrazovanje; znanje.
\end{abstract}

Zašto temelji našeg društvenog sustava koji uključuju i svoju političku konotaciju - vlastitu sastavnicu, znanu ali nepriznatu te nedovoljno značajno tretiranu, podsjećaju na "gorko vino“? Iz naslova je vidljivo da se misli na aktualne procese, kontekst i moguće intervencije u odgojno-obrazovnom sustavu. I to cjelovitom, od predškolskog perioda do sveučilišne, akademske razine - sve obogaćeno cjeloživotnim, permanentnim učenjem. Pojedinci misle da im to ne treba jer previše ili dovoljno znaju, ili se ne žele angažirati, ili suviše kritički procjenjuju i ocjenjuju društveno-političke okolnosti, odgovorne pojedince, moguće suradnike, ili ne vide svrhu i korist (prosvjetnu ili osobnu) od bilo kakvog angažmana. Nekima praktični izazov novih stremljenja ne znači mnogo, ne vide perspektivu, ne osjećaju potrebu za užitkom uspjeha u radu. Bez obzira na mo- 
guće probleme, zastoje... I zato se istima pristup odgojno-obrazovnoj temi čini čašom gorkog vina. Oni vole slatko, da drugi za njih kreiraju, a tada će imati mogućnosti kritizirati nečije napore, dobrohotne namjere i trud. Njihova će gorčina ostaviti traga. Ali vino amaro ima svoju boju, delicijsku notu, svoju pikantnost $\mathrm{i}$ gorčinu bez razvodnjenosti. A to su procesi odgoja i obrazovanja koji čine bazu svih vrijednosti. Riječ je o rezultatu provedbe ovih procesa. $\mathrm{O}$ znanju.

Što znanje znači? Podlogu za praktičnu primjenu u gospodarstvu, u komunikacijskom diskursu, u bogatstvu odnosa među stručnim i manje stručnim ljudima. Znači primjenu u kvalitetno oblikovanom i strukturiranom društvenom kontekstu koje će samo uz pomoć znalaca i znanja postati funkcionalno. Tako će se uspostaviti strukturalno-funkcionalne djelatnosti koje će nadići svoju sveprisutnu deklarativnost i postati operativne u provedbi ostvarenja ciljeva i zadataka svoje struke/djelatnosti. Na taj će način i djelovanje obrazovno-znanstvenih institucija, ali i gospodarstvenih i svih ostalih, nadići svoju nefunkcionalnost koja sama po sebi nikamo ne vodi.

Stoga je Hrvatska akademija znanosti i umjetnosti, svjesna razočaravajućih činjenica, iznjedrila dokument nazvan Deklaracija o znanju (2004.). Govoreći o razvoju obrazovanja, navodi se da je "glavni trend obrazovanja u 21. stoljeću (je) orijentacija na transferni potencijal učenja: orijentacija na kvalitetno stjecanje manjeg opsega trajnih znanja koja se aktivno usvajaju i prikladna su kao trajna podloga za daljnje permanentno učenje tijekom čitavog života. Na taj se način razvijaju sposobnosti rješavanja problema, a ne gomilaju se obrazovni sadržaji iz društva prošlosti koje se mijenja. Među važnim faktorima obrazovanja ističu se: razvojna orijentacija i treća znanstveno-tehnološka revolucija, interdisciplinarnost u nastavi, razvoj kreativnosti, razvoj i poticanje radnih navika i poduzetničkog duha, razvoj ekološke svijesti, te odgoj slobodnih ljudi, cjelovite i humane ličnosti". U tim mislima izražena je suština odgojnih i obrazovnih ciljeva na putu usvajanja znanja.

No primjena znanja na putu razvojne filozofije i razvojne prakse u svim segmentima društva temelji se i na znanstvenom radu. A u spomenutoj Deklaraciji o znanju utvrđuje se činjenica da je „u znanstvenom radu prva i trajna zadaća poboljšanje kvalitete i primjena svjetskih kriterija vrednovanja. Rasadnici znanja i njegove primjene trebaju biti centri izvrsnosti na sveučilištima, javnim i privrednim institutima. Znanost uključuje tri bitne karike: fundamentalnu, primijenjenu i razvojnu. Glavni financijer fundamentalnih istraživanja treba biti država, a primijenjenih i država i drugi naručitelji. Razvojna istraživanja su najskuplja i izvode se pretežito u istraživačkim institucijama u privredi i financira ih uglavnom privreda." 
Ovo dobro zvuči, koncepcijski gledano, ali - pitanje je je li realno provedivo. Nedostaje odgovarajuća materijalna podrška od strane države (pitanje političke politike), a razvojna istraživanja koja su najskuplja imaju najveću težinu upravo zato jer su razvojna i još su ovisna o gospodarstveno-privrednim ustanovama. Budući da se dominantno provode $u$ istraživačkim institucijama, centrima izvrsnosti vezanim uz sveučilište te institutima, pitanje je obrazovne politike, strategije obrazovanja, koliko se važnosti pridaje, odnosno sredstava daje takvim institucijama. Istina, generalno gledajući, na državnoj je razini mnogo raznoraznih instituta. Jesu li svi funkcionalni? Je li učinjen odabir kvalitetnih (na bazi evaluacije) s odgovarajućim rezultatima. A rezultate ostvaruju ljudi, svojim potencijalima (human resource development). Čini se da se svima pristupa jednako (uravnilovka). Ali, uz postojećih tridesetak instituta, nitko se nije zapitao: gdje je institut za obrazovanje ili institut za obrazovne studije (npr. Južna Afrika ima Institute for Advanced Study) - dakle, naglašena kvaliteta i visoka razina naprednih studija. A mi, u srcu Europe, u čije se obrazovne dosege kunemo, nismo u stanju domisliti odgovarajuću instituciju koja bi svojim konceptom odgovarala izvrsnosti i bila adekvatno financirana.

To govori o nezainteresiranosti, kao i o neshvaćanju da su procesi odgoja i obrazovanja - iako odvojeni kao pojmovi, isto su tako u sinergijskoj funkciji vrh strateške piramide, ali i temelj primarnog djelovanja u svim segmentima društva. Jer bez znanja nema ostvarive kompetencije u svim strukama (ekonomija, medicina, pravo, arhitektura i dr.), a posebice u nastavničkoj profesiji. No tu je riječ i o kompetitivnosti, koje nema bez razrađene/razvijene unutarnje potrebe za natjecanjem, za utvrđivanjem vlastitih dosega. Kada takvi motivi zavladaju potrebom za permanentnim razvojem i dokazivanjem sebi i drugima, kolektivna će svijest imati podlogu za daljnji razvoj osobnih, profesionalnih i širih društvenih odnosa. Bez toga ostajemo u prošlosti jer ovako nam ne treba ni dosljednosti ni postojanosti ideja, njihovih realizacija, primjena... Tako pojedinci ostaju jednako nedosljedni jer nemaju što kvalitetno slijediti. Slikovito rečeno sveukupna premreženost pokriva pasivna stanja, bezidejnost, neodgovornost te čini gužvanje na isušenoj zemlji koja ne daje ploda.

Ovako diskutabilan i relativiziran pristup nacionalnim institucijama potkrijepljen je i nejasnim programima koji se najčešće multipliciraju u svojoj sličnosti i ne pridonose unapređivanju nastavničkih kompetencija. Kakve ishode, rezultate, teorijske i praktične, možemo očekivati? Je li riječ o znanju (knowledge) ili o ishodima (outcomes)? Znanje je lako provjeriti konkretnim pitanjima, a ishode je teže „Vrednovati“ jer su dani široko, općenito, pa ih treba u zahtjevu, formulaciji dotjerati, dopuniti, pojasniti, konkretizirati. Utvrđujući ishode, teško je utvrditi 
što je tu minimum, a što maksimum učeničkih/studentskih ishoda. Ishodi učenja imaju korijene $u$ definiranju ciljeva kao mjerljivih rezultata učenja, kao instrument razvoja. Primjena tabličnog prikazivanja, evidentiranja i specificiranja ishoda ne pridonosi ničemu osim što nastavnikov rad i cijeli odgojno-obrazovni proces čini kompliciranim i birokratskim. A mi bismo željeli kreativnost $\mathrm{u}$ pristupu i rezultatima, primjenu kritičkog mišljenja, odgovarajući pristup problemskoj nastavi i rješavanju problema, interakciju i na tom tragu oblikovanje inovativnih sadržaja, metoda, postupaka, kombinacija.

Slijedom toga javlja se i potreba za ostvarenjem psiholoških standarda kompetencija ličnosti koji su baza svakog promišljanja, svake inovacije, a odnose se na sljedeće:

1. na postizanje etapnih i cjelovitih rezultata (pitanje psihološkog sagledavanja problema);

2. na oblikovanje snage identiteta ličnosti;

3. na formiranje hrabrosti za izražavanje vlastitog stava, ideja, istupa - pa makar se oni kosili sa stavovima ",autoriteta" na funkcijama zbog mogućih prijepora;

4. na oblikovanje sustava odgovarajućih kriterija i vrijednosti (intelektualne, moralne radne...);

5. na postizanje sposobnosti za izražavanje argumentirane kritičnosti;

6. na ostvarenje autoriteta temeljenog na kvalitetama osobnosti;

7. na ostvarenje odgovornosti prema sebi i drugima kao stupanj kvalitete upravljanja svojom ličnošću, obrazovnim procesima kojih smo dio;

8. na razvoj komunikacijskih sposobnosti i na njima temeljenoj socijalizaciji.

Rekli bismo da su spomenuti procesi nužni standardi koje valja respektirati na teorijskoj razini i zatim praktično provoditi ako želimo kvalitetnu provedbu reforme (je li to prava riječ?) kao trajnog procesa koji iziskuje kvalitetne pomake.

$\mathrm{Na}$ sve te procese, psihološke standarde kompetencija ličnosti, ne bi smjele utjecati društveno-političke pojave i promjene koje se odnose na promijenjene okolnosti i odnose s drugim političkim entitetima. Isto tako na njih ne bi smjele utjecati ekonomske promjene koje su inače varijabilne ili standardno niske (nezaposlenost, migracijska politika koje nema, demografska slika koju ne bi trebalo „uokviriti“ za trajna vremena, neupotrebljivost stečenih diploma i dr.). Također na njih ne bi smjela $u$ obrazovnom smislu utjecati multiplikacija znanja i informacija koja bi se trebala distribuirati na povećani broj stanovništva u svijetu, a smanjen natalitet $\mathrm{u}$ nas. Mora se priznati - zanimljiv reciprocitet. Također se to odnosi i na pojedine sveučilišne odjele i odsjeke pojedinih fakulteta čiji završeni 
studenti ne mogu naći posao u struci, pa su osuđeni na nižerangirane poslove. Isto tako na te procese ne bi smjele djelovati informacijsko-komunikacijske, odnosno tehnološke promjene i unapređenja. A djeluju. Od mobilne telefonije (asocijalno ponašanje $u$ društvu te nedostatak komunikacijskih odnosa s okolinom) preko novih računalnih programa i tehnoloških procesa. U SAD-u već djeluju kvantni kompjuteri, a mi smo tek jedva čuli za njih. Naši eminentni kvantni fizičari pokušavaju dokučiti značaj i primjenu, ali dok se praktično ne susretnu s takvom „igračkom“, teško da se itko može familijarizirati s tom temom.

Nažalost, sve ove globalne, regionalne i lokalne promjene (društveno-političke, ekonomske, obrazovne, informacijsko-tehnološke) djeluju itekako na kvalitetu spomenutih psiholoških standarda kompetencija ličnosti. Ali i traženih profesionalnih kompetencija. Prema upitniku Tuning Educational Structures in Europe, dakle, TUNING projektu, one se dijele na opće (generičke) i specifične. Bez ranije spomenutih psiholoških, pa i pedagoških kompetencija ličnosti kao baze za usvajanje barem dijela generičkih kompetencija teško da će se ostvariti širi socijalno-radni koncept djelovanja. Tako ovaj projekt definira tridesetak najtipičnijih generičkih kompetencija koje se dijele u tri skupine:

1. instrumentalne kompetencije (kognitivne sposobnosti, metodološka znanja, tehnološke i jezične vještine);

2. interpersonalne kompetencije (individualne sposobnosti izražavanja emocija, kritičke sposobnosti, socijalne kompetencije, timski rad, društveni angažman);

3. sistemske kompetencije (čine kombinaciju razumijevanja, senzibilnosti i znanja koja omogućuju povezanost dijelova i funkcioniranje cjeline).

Navedimo nekoliko instrumentalnih kompetencija koje nam se čine posebno zanimljive: sposobnost analize i sinteze; sposobnost planiranja i upravljanja vremenom; temeljno opće znanje struke (studijska područja); usvojena osnovna praktična znanja; kvalitetna komunikacija na materinskom i drugom stranom jeziku; osnovne vještine rada na računalu; vještine upravljanja informacijama (sposobnost prikupljanja i analiza informacija iz različitih izvora); sposobnost rješavanja problema; sposobnost donošenja odluka.

Neke od interpersonalnih kompetencija odnose se na: sposobnost kritike i samokritike; interpersonalne vještine; sposobnost rada u interdisciplinarnom timu; sposobnost komunikacije s osobama koje nisu stručnjaci; uvažavanje raznolikosti i multikulturalnosti; sposobnost rada u međunarodnom okruženju.

Složenost daljnjih kompetencija odnosi se na sistemske kompetencije, a one tretiraju: sposobnost primjene znanja u praksi; istraživačke vještine; sposobnost 
učenja; sposobnost prilagodbe novim situacijama; sposobnost stvaranja novih ideja (kreativnost); sposobnost rukovođenja; razumijevanje različitih kultura; sposobnost samostalnog rada; sposobnost oblikovanja projekata i upravljanja njima; inicijativnost i poduzetnički duh; želja da se ostvari kvaliteta; sve to s ciljem ostvarenja uspjeha.

Generalizirajući navedene kompetencije te objedinjujući osnovne generičke vještine, valja praktično pojasniti na što se konkretno one odnose - na pojedinim primjerima:

1. osnovne vještine (jezična, numerička, tehnička, notna i druge pismenosti);

2. ljudske sposobnosti (komunikacijske i timski rad...);

3. konceptualne vještine (prikupljanje i organizacija podataka, učenje kako se uči - inovativno, kreativno, sustavno);

4. osobne vještine (odgovornost, upravljanje vremenom, samokontrola...);

5. poslovne vještine (poduzetnička, menadžerska, marketinška...);

6. društvene vještine (stavovi, socijalna odgovornost, angažiranost...);

7. psihološke vještine (komunikativnost, empatija, emocionalna inteligencija, poticanje promjena, upravljanje konfliktima...).

$\mathrm{Na}$ osnovi tih specifikacija vidljivo je da nije samo znanje faktor uspjeha. Važne su tu vještine i sposobnosti. Ovisno o kojoj se struci i kakvoj primjeni u praksi radi. Analizirajući navedene tri skupine generičkih kompetencija, uočila se povezanost s vrlo poznatom i priznatom Bloomovom taksonomijom (1956.) kognitivnih ciljeva i zadataka učenja. Dakle, modaliteti su prisutni i podložni vremenu i shvaćanjima, ali suštinska određenja uglavnom ostaju ista. Tako Bloom reda svoje kognitivne ciljeve učenja ovako: dosjećanje/znanje; razumijevanje; primjena; analiza; sinteza; vrednovanje (evaluacija) - s temeljnim ciljem kreativnosti. No primjena te taksonomije nije uvijek odgovarajuća. Problem je naprimjer s matematikom. Razlog je dubina znanja te pojavnost moguće slojevitosti i kombinatorike s drugim područjima matematike poboljšavajući pritom postojeće modele. To je tzv. prijenos ili transfer znanja koji nije uvijek i u svim procesima prisutan.

Iz svega proizlazi da ishodi kako smo ih ranije tretirali pokrivaju opću dimenziju znanja i sposobnosti, teško ih je precizirati, pa ih možemo svesti na tri vrste ishoda: kognitivne, afektivne i psihomotoričke. Istovremeno, ispit znanja uvijek je konkretan, pitanja specificirana, pa su onda i odgovori jasni. Imajući u vidu ta tri generalna, opća ishoda, valja voditi brigu i o društvenim standardima koje je još 2006. godine Europski parlament donio u svojem referentnom okviru CARDS programa za osam ključnih kompetencija koje oblikuju 
znanje i obrazovne kompetencije. To su: matematičko-logička kompetencija koja podrazumijeva i prirodne znanosti (fizika, kemija, biologija); komunikacija na materinskom jeziku; komunikacija na stranom jeziku; kompetencija učenja (znati kako se uči); digitalna kompetencija; smisao za poduzetništvo i inicijativu; kulturološka senzibilizacija i izražavanje (kultura govora i komunikacije - što u nas frapantno nedostaje, te umjetničko odgojno formiranje ličnosti kroz literaturu, teatar, izložbe, koncerte itd..); društvene i građanske kompetencije (program predmeta Građanskog odgoja za osnovne škole već duže čami u mraku birokratskih ladica, a toliko je nuždan za mlade - što je, nažalost, tragično vidljivo kad ti isti mladi dođu na fakultetski studij i nemaju elementarnu kulturu ponašanja; sve budući neprikosnoveni intelektualci i vođe ovog društva...).

Ako se bolje sagledaju spomenute kompetencije, onda je jasno da se one odnose uglavnom na postojeće školske predmete. No koliko će ti predmeti biti kvalitetno izvođeni ne ovisi toliko o samom programu koliko o kvaliteti nastavnika i spremnosti učenika, kasnije studenata, da aktivno sudjeluju u nastavi i usvajaju materiju, kritički promišljaju, kreativno pristupaju problemima, a to znači inovativno djeluju na obrazovni/nastavni proces. Na tom putu očekuju se kvalitetniji ishodi i znanja koncipirani na ovaj način. Kako su zacrtani ishodi kognitivne, afektivne i psihomotoričke naravi, iste te vrijednosti pretpostavkom su uspješnosti. Dakle, racionalne i emocionalne komponente i vrijednosti temeljne su odrednice kvalitete i razine samog nastavnog procesa kao i nastavnika. Bez obzira na to radi li se o osnovnoj, srednjoj ili strukovnoj školi ili sveučilišnoj nastavi ponajviše. Racionalni dio podrazumijeva šire poznavanje problematike o kojoj se govori, kao i opću, te pedagoško-psihološku kulturu nastavnika. Dok emocionalni dio podrazumijeva senzibilizaciju za problem, aktivan odnos prema temi, odnosno problemu (želja za rješenjem, pomoć i dr.). Psihomotorički dio ovdje nije toliko eksplicitan jer se oslanja na praktična znanja i iskustva - vezano više uz empirijske dokaze, eksperimentalne i informacijsko-tehnološke teme kao i strogo fizičke zadatke vezane uz strukovne škole. No bez obzira na to o kojoj se obrazovnoj razini radilo, akceptirati treba nekoliko ključnih zadataka u realizaciji, a to su: atraktivnost nastave (sadržaja, metoda, tehnologija...); mobilnost (nastavničku, studentsku/učeničku, istraživačku na međunarodnoj razini); usporedljivost s inozemnim (visokim) obrazovanjem i kvalifikacijama; osiguranje kvalitete cjelokupnog obrazovnog korpusa - komparacija s inozemnom scenom.

Stoga možemo govoriti o profesionalnim (stručnim) i pedagoškim kompetencijama nastavnika - bez obzira na to o kojoj se obrazovnoj razini radilo. Profesionalnost se veže uz dobro poznavanje vlastite struke (vrstan liječnik, agronom, ekonomist...), a pedagoške kompetencije više se pridaju nastavničkoj 
profesiji vezano za nastavu osnovne i srednje škole. A što je s nastavnicima, poglavito mlađim, asistentima, koji su kao kvalitetni studenti zadržani na fakultetu ali nemaju nikakav pojam o pedagoškim zakonitostima i procesima, psihološkim, didaktičkim i metodičkim. Tu bih uključila i sociološke te komunikacijske/govorne aspekte odgovarajuće profesijete, koji su vrlo važni i temeljem su svake profesije zbog uspostavljanja odnosa s vlastitim studentima i strankama, pacijentima, suradnicima... Sama profesionalna, stručna "težina“ nije kompletna ako uz nju nije vezana pedagoška i komunikacijska komponenta.

Dakle, ova konstatacija rezultat je pokazatelja iz prakse i zahtijeva postojanje navedenih kompetencijskih elemenata za sve sveučilišne nastavnike bez obzira radilo se o nastavničkom ili nenastavničkom fakultetu. Naime, svim zaposlenima u osnovnim, srednjim i strukovnim školama ta spoznaja vrlo je prisutna jer, prema Zakonu, ako žele raditi u školi, taj proces moraju proći. Samo to isto ne moraju proći sveučilišni nastavnici. No kao što bismo se u mnogim stvarima željeli ugledati u inozemna iskustva, taj pedagoški segment nekako smo zapustili. Naime, u europskim zemljama djeluju institucije koje o takvim pitanjima dodatne edukacije itekako vode brigu. Primjerice, University of London kao svoju jaču znanstveno-obrazovnu jedinicu ima Institute of Education. Jedna od zadaća tog instituta jest praćenje obnavljanja licenci za rad u nastavi svakih 3 - 5 godina. Što znači novu, dodatnu edukaciju, nove spoznaje iz pedagoškopsihološke te didaktičko-metodičke domene ranije spomenutih sadržaja. To je ujedno pokazatelj da je problematika ozbiljna s obzirom na to da se radi s mladom generacijom i budućim kreatorima društva. Bez takve licence nema rada $u$ nastavi. Takve institucije davno su oformljene kako u Velikoj Britaniji, tako i u SAD-u (Stanford i Talahasy), Njemačkoj (Münster), Austriji, Sloveniji i dr. I njihov rad osjeća se u praksi. Podsjetila bih na Institut za napredne studije u Južnoj Africi s početka ove priče koji se svojim sadržajima i programima uklapa u ovu problematiku. Sve takve djelatnosti podrazumijevaju interdisciplinarnost, multidisciplinarnost, internacionalnost. Kad bismo tome dodali razvijanje raznih oblika pametne specijalizacije (o kojoj se vatreno govorilo), to bi bila osnova za međufakultetsku povezanost koja bi utjecala na razvoj gospodarstva u svojoj horizontalnoj prohodnosti.

Sve to implicira pretpostavke cjeloživotnog učenja/obrazovanja (lifelong learning) na temelju dokumenata Europske unije kao što su: Horizon 2020, Europe 2020, Teaching 2020 (za osnovne škole) i Green Paper kao temeljni dokument očekivanih zadataka i promjena te usklađivanja svih europskih programa - uvažavajući pritom i specifičnosti svake pojedine zemlje. Vezano uz cjeloživotne procese obrazovanja i stečena znanja i sposobnosti te njihovu primjenu, važno je sagle- 
dati posljedice takvog obrazovanja u tržišnoj orijentaciji i uskoj sprezi između obrazovanja i gospodarstva. Pronalaženje odgovarajućeg posla (što je danas sve rjeđe) podrazumijeva i paralelno ili naknadno uključivanje $u$ obrazovni proces radi usavršavanja u znanju i struci. Nekad davno to je bio vrlo aktivan proces povratnog ili rekurentnog obrazovanja koje je još 1973. godine OECD zacrtao kao strategiju cjeloživotnog učenja (Lifelong Learning, LLL). U kojoj je mjeri to moguće danas ostvariti, veliko je pitanje. Jer usavršavanja se odnose na pronalaženje novih sadržaja, novih programa i novih poslova. Širenje horizonta i dostupnost novim spoznajama vrijedna je nakana, ali pod pretpostavkom da se prethodno ima posao. Usavršavanje u nečemu za posao za koji se ne zna hoće li se dobiti mnogima je uvjetovano trenutnom materijalnom situacijom, a ne obrazovnim motivima.

Bivši predsjednik Vlade RH i još i danas aktualni rektor Sveučilišta u Zagrebu dogovorili su analizu postojećih programa svih fakulteta koji uzajamno korespondiraju vežući sadržaje, znanja i razvoj sposobnosti između visokog obrazovanja i gospodarstva - zbog lakšeg i bržeg zapošljavanja mladih poslije diplomiranja. Ne sjećam se da smo čuli za rezultate takva istraživanja niti da je $\mathrm{u}$ tijeku takav proces. Istina, to bi bio golem posao i ne znam tko bi, na temelju nalaza koji bi uslijedili (govorim iz vlastitog iskustva), ostao raditi i koji bi programi, makar i dotjerani, dobili na značaju i primjeni. Sreća po rektora da ondašnji predsjednik Vlade više nije na toj funkciji, a rektor na svojoj funkciji može ostati i bez takvih analiza.

Prema tome, određenje kvalitete sveučilišne nastave i uspješnost nastavnika razmatraju se kroz prizmu motiviranosti studenata (motivi su različiti), prolaznosti studenata na ispitima (i tu su razlozi mladih zašto se žure položiti ispite ili pauziraju po nekoliko godina individualni), dužina studiranja, odabir struke (neefikasno trošenje vremena zbog nemogućnosti zapošljavanja)... U svakom društvu događaju se promjene koje uvjetuju i promjene u obrazovanju. Uz to je vezana ekonomija društvenih procesa jer njezina stanja znaju biti istovremeno i uzrok i posljedica svakodnevnih događanja. Zbog perspektivnih gledanja, ulazi se u projekte i promjene (uzrok), a zbog financijskih skeptičnih okolnosti i razmišljanja odustaje se od ideja, kreiranja poslova i svakog angažmana (posljedica). Stoga bi tu trebala nešto učiniti politika obrazovanja koju čine prosvjetna politika i društveni razvoj koji su međusobno uvjetovani, a rezultat su društvene politike i politike financiranja. Koliko god da se reformskim zahvatima za mlade ponešto i čini, ne čini se gotovo ništa za andragošku populaciju (vocational education) jer se ne zna iskoristiti njihovo prethodno iskustvo i znanje. Za daljnji napredak $\mathrm{u}$ obrazovanju odraslih treba respektirati karakteristike tog procesa, 
a to su: motiviranost (pojedinaca i društva), prilagodba programa polaznicima, heterogenost polaznika (na razini znanja, iskustva, profesije...), grupna šarolikost (mlađi i stariji), svatko doživljava obrazovanje na specifičan način, različita je društveno-politička, pa i prosvjetna, obrazovna informiranost, razlikuju se i u stupnju elementarne - funkcionalne pismenosti itd.

Sve ove razine obrazovanja pitanje su nacionalne odgovornosti isto kao i cjelokupna obrazovna politika ili politika obrazovanja. Ostvarenje kvalitetnih obrazovnih procesa uvjetovano je strategijom razvojne politike obrazovanja, koja unutar sebe involvira odgovarajuću strukturu, a sve čini cjelovit sustav. Pitanje je kakav. Podsjetila bih na dokument nazvan Plan razvoja sustava odgoja i obrazovanja (za razdoblje 2005. - 2010.), u kojem su zacrtani prioriteti profesionalnog, stručnog usavršavanja radi stjecanja znanja i umijeća. Iz tog dokumenta proizlazi cijeli niz točaka, a mi ćemo se zapitati što je od toga do danas učinjeno. Pa pogledajmo - komentar prepuštam čitatelju:

1. razvoj cjeloživotnog učenja i obrazovanja;

2. decentralizacija sustava obrazovanja - autonomija (potpora regionalnom razvoju što utječe na razvoj veleučilišta i zapošljavanje mladih u njihovu kraju - Požega, Virovitica, Knin, Vukovar i dr.);

3. pitanje političkih i društvenih utjecaja („politička elita“);

4. horizontalna i vertikalna povezanost: obrazovni, kulturni kapital, ljudski potencijal - treba tretirati kao trajnu vrijednost;

5. trajno profesionalno usavršavanje natavnika na svim razinama od osnovne škole do fakulteta - sveučilišni nastavnici profiliraju svoje studente, buduće nastavnike, koji opet u svojem radu educiraju mlađe naraštaje;

6. osnažiti strategiju i strukturu politike obrazovanja;

7. poraditi na gospodarskoj, ekonomskoj efikasnosti u sprezi s obrazovanjem;

8. pitanje organizacije javnih i privatnih učilišta (veleučilišta, sveučilišta).

Za primjenu i razvoj strategije, strukture na putu oblikovanja sustava obrazovanja (3S) nužne su kompetencije koje provociraju kompeticiju (bez natjecanja i borbe prioriteta nema uspjeha jer nema motiva), a ona je odraz konkurencije. Sve će rezultirati kvalitetnijim ishodima, rezultatima obrazovanja. Ova 3K u suglasju s $3 S$ omogućit će realizaciju osiguranja kvalitete prema Europskoj asocijaciji za osiguranje kvalitete $\mathrm{u}$ visokom obrazovanju (ENQA = The European Association for Quality Assurance in Higher Education), koju čini 40 agencija za osiguranje kvalitete. Komparacija je neminovna, ali i nužna. 
Na putu realizacije kvalitete svjedočimo zatvorenim komunikacijskim odnosima i tako se onemogućavaju procesi utjecanja na razvoj kvalitete u svim segmentima. Želimo li rezimirati neke spoznaje iz negativne prakse, valjalo bi specificirati određene zahtjeve:

1. na putu profesionalizacije i razvoja cjeloživotnog učenja kompetencije imaju svoju razvojnu ulogu;

2. ciljevi i metode trajno se mijenjaju, a na putu njihova ostvarenja treba poraditi na motivaciji;

3. kvalitetno primijeniti nacionalni sustav za osiguranje kvalitete $\mathrm{u}$ visokom obrazovanju (ne samo u osnovnim i srednjim školama);

4. pratiti rezultate europske mreže za osiguranje kvalitete ENQA i komparirati rezultate;

5. osigurati horizontalnu i vertikalnu prohodnost - ne samo u pisanoj formi;

6. osigurati rast $\mathrm{u}$ kvalitativnom i kvantitativnom smislu;

7. poštivati i osigurati pedagoški standard posebno u visokom obrazovanju, i to u njegovu sadržajnom, personalnom i strateško-funkcionalnom dijelu;

8. osigurati pedagošku izvrsnost, odličnost (exellence) - primjer zaposlenika u agencijama, sveučilištima, ministarstvu (mladi i pedagoški neformirani);

9. permanentno osposobljavanje nastavnika svih razina (po uzoru na europske i svjetske institucije);

10. poraditi na kvalitetnoj zakonskoj regulativi koja bi osigurala mjerljiv ishod učenja;

11. standardizirati evaluaciju kako bi se izbjegle poklonjene ocjene, zataškavanje problema, nekritičnost, paralelne instrukcije iz pojedinih predmeta - čemu služi škola.

Ovo su samo neki od zahtjeva koje bi valjalo maksimalno respektirati. Pogledajmo rezultate jedne ankete održane na nastavničkim fakultetima i njezine rezultate - što su studenti zamijetili i zamjerili kreatorima obrazovnog procesa na njima. Čini se da iz tih odgovora proizlazi sva gorčina spomenuta u naslovu teksta.

Evo mišljenja studenata:

1. postoji manjak prakse, tj. metodike u nastavi studija (pitanje kako nešto izvesti);

2. prisutan je višak teorije, i to ponavljane s različitih uglova od različitih predavača; 
3. nevaljala je logika cjelovitog studija;

4. nedostatak terenskog i istraživačkog rada;

5. nespremnost za tržište rada;

6. neprestane kolizije između dva obvezna kolegija - neorganiziranost;

7. veliki su troškovi prilikom prelaska s preddiplomskog na diplomski studij;

8. neusklađenost ECTS bodova;

9. prepuštenost vlastitim potencijalima ako žele na mobility, study visit ili razmjenu bilo koje vrste;

10. slaba međunarodna razmjena - ničim poticana;

11. nema gostujućih profesora koji bi proširili horizonte i potaknuli međunarodne kontakte;

12. zaustavljanje mladih u napredovanju, pa čak i kolega profesora;

13. loši zakoni koji sputavaju obrazovne i kadrovske razvojne procese itd.

Pa sad, ako su učenici/studenti centar kojem trebaju biti prilagođeni sadržaji, oblici rada, studijski posjeti i sve što se tiče kvalitete studija, onda za to trebaju nastavnici biti posebno educirani. Jesu li? I je li nekome iz vrhovnog miljea do toga stalo? Ipak su, izgleda, nastavnici (ne svi, samo odabrani) još uvijek centar svijeta - sveg svijeta uz nekoliko muzgavaca koji ih okružuju. Od toga nema koristi.

S obzirom na činjenicu da su u tijeku neproduktivni reformski procesi bez cjelovite slike i koncepcije, bez sustavnog i terminskog određenja zadanih aktivnosti izostaje i pregledna struktura cijele tako složene i odgovorne procedure izvođenja promjena $\mathrm{u}$ kontekstu reforme obrazovnog sustava. Zato su na dijelu odugovlačenja i gubitak vremena i kapaciteta, čak ljudskih potencijala osoba koje su zainteresirane za uspjeh i korisne reformske zahvate.

Činjenica je da kad god nešto poželimo mijenjati uvijek krećemo ab ovo. Je li to potrebno? Naravno, nije. I uvijek se kreće od osnovne škole. Ne tvrdimo da tamo ne treba nešto mijenjati, ali trenutni stihijski orijentiri s uvođenjem informatike samo su primjer nesustavnog djelovanja u odgojno-obrazovnom prostoru. Jest, tehnologija napreduje, potrebna je njezina primjena u školama, ali početi od toga kao tehnološke baze za rad $s$ djecom koja još nisu naučila elemente ostalih tradicionalnih predmeta/sadržaja nije metoda koja bi podgrijala kvalitetan razvoj reformskih događanja, tim više što tehnologija napreduje geometrijskom progresijom i traži nove promjene, što znači nova informatička znanja, ali i novu tehnologiju.

Stoga se zalažemo za dalekosežniji i sveobuhvatniji pristup reformskim potezima. S njima se mnogi sveučilišni profesori i studenti slažu. O čemu se radi? 
Da bismo imali kvalitetan predškolski, osnovnoobrazovni, srednjoškolski sustav, pa i visokoobrazovni, poželjno je ići obrnutim redom. S reformom se ne počinje iz sredine (OŠ, SŠ) nego od vrtića (što nije potrebno jer tamo su mali konzumenti) ili od fakulteta, tj. sveučilišta, gdje su veliki problemi. Stoga je nužno poraditi na sustavnim, programskim, organizacijskim i inim promjenama na razini visokog obrazovanja revizijom bolonjskog procesa. Preporuka, gotovo nalog, o reviziji bolonjskog procesa objavljena je u Erevanskom ministarskom priopćenju s Erevanske ministarske konferencije (Yerevan Communique, 2015.). $S$ obzirom na niz negativnih pokazatelja provedbe visokoškolske nastave, njezine organizacije i programa, bolonjski je proces stavljen pod upitnik. Mnoge zemlje već su ušle u proces analize i restrukturiranja. Međutim, mi još nismo ni započeli, a svjesni smo svih negativnosti koje otežavaju rad u fakultetskoj nastavi.

$S$ tim u skladu poželjno je revidirati i restrukturirati institucionalnost sveučilišta kao glomazne ustanove koja ne može (sve i da zna) pokrivati znanstveno, stručno, medijski, financijski, pa čak i ljudski sve potrebe koje razvoj i različitost u postojanju tridesetak fakulteta, i to javnih, državnih, iziskuje. Ne može se sveučilište skrivati iza dodijeljene mu autonomije, koja bi trebala značiti samostalnost u znanstvenoistraživačkom radu, a zapravo predstavlja svojevrsnu anarhiju.

Svi važni, uspješni fakulteti u svijetu imaju renome i institucionalnu organizaciju naslovljenu na sveučilište (university). To omogućuje odgovarajuću brigu za vlastite programe, kadrovske potencijale i potrebe, financijsku strukturu te cjelokupan razvoj. Radi se na vlastitom probitku, kvaliteti svoje struke i svoje institucije. Uglavnom su vezani uz svoje kampuse, gdje studenti mogu komunicirati, surađivati, konzultirati svoje profesore i tako se intimizirati sa studijem i svojom budućom profesijom. Znači, posljedično su okrenuti vlastitoj inicijativi i za sve što učine, dobro ili loše, snose posljedice ili se ponose kvalitetnim rezultatima.

S obzirom na činjenicu da nam je Sveučilište neuređeno, gotovo personalizirano, valjalo bi se osvrnuti i na fakultete koji, s obzirom na svoju veličinu, po broju nastavnika i broju studenata, usko tretiraju svoje izvedbene programe ovisno o odsjecima, katedrama, pa i osobnim interesima (ovisi o temi disertacije, čiji se naslov nakon obrane pretvara u kolegij - kojeg li nonsensa!). Tako dobivamo doktorate i „obranjene“ doktorske kandidate koji nakon svega ne znaju što će s tim. Jedni time pokrivaju radna mjesta, drugi bježe u inozemstvo, treći bi se samo kitili (jer su imali predodžbu da je to lako, nekima i jest, pa što ne bi i oni na promociji bacali kapu u zrak). I sad se postavlja pitanje: gdje su ti mladi 
ili manje mladi znanstvenici. Sjede u laboratorijima, pišu radove, javlja se poneki patent, zaštita autorskog prava, a ništa se doista ne događa, nema primjene ni prosperiteta. Pritom se javlja notorna činjenica da, što je više doktora znanosti, to je više nepismenih $-\mathrm{u}$ doslovnom smislu, ali i kod fakultetski obrazovanih. No to je tema za jedan cijeli elaborat.

Stoga bi se institucijski, s obzirom na nastavnički dignitet, i to fakultetski, trebale organizirati edukacije preko odgojno-obrazovnih sadržaja (pedagoške i didaktičko-metodičke teme), psiholoških tema, socioloških i komunikacijskih, koje nedostaju našim mladim znanstvenicima. Ima još dodatnih sadržaja, ali već su razrađeni i ne bih na ovome mjestu o tome. Tako nešto trebalo bi primijeniti na svim fakultetima, bilo nastavničkim bilo nenastavničkim. Pogotovo se to odnosi na mlađe asistente, docente, pa i druge koji sudjeluju u nastavi obrazujući studente $\mathrm{u}$ stručnom, profesionalnom dijelu. Pitanje je što znaju o tome kako se to radi. Koje metode u kojem trenutku upotrijebiti? Koji su modeli adekvatni? To bi bilo pitanje opće kulture, jednog novog segmenta za mlade znanstvenike koji bi predstavljao novi, kvalitativno i sadržajno drugačiji aneks vlastitoj diplomi i osobnim znanjima. Tim više što bi se time profilirale elementarne funkcije ličnosti - i samih mladih nastavnika i njihovih studenata.

Jesu li ranije spomenuti modeli konstruktivistički (samostalan rad uz interakciju s informacijskim izvorima), ili treba primijeniti konektivizam (razlikovanje bitnih od nebitnih informacija - suština učenja) ili se orijentirati na e-učenje, za koje je potrebna odgovarajuća informatička pismenost, ili preferirati cjeloživotno učenje, kao trajni proces obogaćivanja sadržaja, učiti perspektivno za cijeli život. Ima različitih načina, metoda, sustava, modela. Nijedan od njih nije samostalan $\mathrm{i}$ dovoljan, valja ih u primjeni obogatiti kombiniranjem klasičnih predavanja, vebinara i e-učenja, kvalitetne metodičke prakse i ostalih ponuđenih „instrumenata“.

U svojoj dugogodišnjoj radnoj praksi iskustvo mi je pokazalo da u sveučilišnoj nastavi nedostaje nešto što smatram temeljnim nedostatkom visokog obrazovanja. A to je komunikacijska psihologija koja nije oblikovana kao predmet, ali bi nužno trebala objediniti sadržaje nedostatne komunikacije. I to psihološki obojene. Jer, nastavnik sa studentom razgovara na jedan način, liječnik s pacijentom ili pacijentima na specifičan način (svaki čovjek zaseban je kapacitet), agronom s ljudima vezanim uz prirodu komunicira na svoj način itd. Te specifičnosti valja respektirati i znati primijeniti. Takve sadržaje trebalo bi povezati s područjem socijalne psihologije, koja je šire i bogatije aspektirana. Ali pitanje je - kome to treba.

$\mathrm{Na}$ tragu potencijalnog reformiranja aktualnih visokoobrazovnih procesa valja reći da bi se ti procesi trebali sustavno realizirati $u$ formi tri reforme $u$ jednoj cjelovitoj: 
1. sadržajno-programska (unutarnja reforma);

2. organizacijska (vanjska reforma);

3. pedagoško-psihološka i didaktičko-metodička (kao zajednički nazivnik za vanjsku i unutarnju reformu).

Pritom se ne bi smjelo tolerirati sveučilišnim nastavnicima formiranje navika, stereotipa, ukalupljenosti...) već ih treba osvijestiti u potrebama, orijentirati i profilirati prema potrebama prakse, $t j$. prema studentima.

Zanimljivo je pogledati samo nekoliko faktora „propasti“ dosadašnjeg koncepta reforme:

1. ljudski potencijali i njihov stupanj zainteresiranosti (nastavnici);

2. (ne)adekvatni programi - neprilagođeni;

3. (ne)zainteresiranost društva - politike;

4. (ne)ozbiljnost u realizaciji procesa;

5. (ne)odgovornost organizacija, pojedinaca, struktura....;

6. (ne)upućenost, (ne)informiranost subjekata kojima je reforma namijenjena;

7. nema suradnje istih, sličnih ili različitih struka - pojava izoliranosti;

8. neadekvatan odnos između sveučilišta i pojedinih fakulteta što se reflektira na nižu razinu, na osnovne i srednje škole.

Uz javna, državna sveučilišta i fakultete postoje i privatna visoka učilišta, veleučilišta, čak i jedno privatno sveučilište (Libertas). Pitanje je kako i s kojim ingerencijama oni funkcioniraju u odnosu na javna sveučilišta i brojne fakultete. Na privatnim učilištima/veleučilištima/sveučilištu radi se prema kriteriju javnih sveučilišta zapravo o fakultetu (1) i visokim školama, akademijama preraslim u visoko učilište ili sveučilište (1). Ovdje tu temu tek spominjemo, ali prethodno spomenuti sadržaji 3 reforme (all in one) trebali bi također biti dijelom inovativnih promjena. Tim više što se uvijek radi o ustanovama studija ekonomske orijentacije koje nemaju sadržaje odgojno-obrazovnih znanosti, a trebale bi, s obzirom na to da i one sudjeluju u visokoobrazovnom procesu.

Ciljevi postizanja takve profesionalne, ali i time objedinjene pedagoške, dakle odgojno-obrazovne izvrsnosti, ogledali bi se u svjetlu sljedećih procesa:

1. planiranju razvoja pedagogijske teorije i pedagoške prakse;

2. poticanju obrazovne izvrsnosti;

3. upravljanju promjenama u razvoju sustava visokog obrazovanja;

4. utvrđivanju postojećih nastavničkih i drugih kompetencija kao daljnjeg razvoja profesionalnih vrijednosti; 
5. razvoju novih nastavnih programa primjenjivih u visokom obrazovanju i gospodarskim organizacijama;

6. zajedničkom djelovanju i razvoju obrazovnih i gospodarstvenih struktura;

7. konkurentnosti na tržištu u znanjima i vještinama;

8. osiguranju provedbe cjeloživotnog obrazovanja i kvalitetne profesionalizacije;

9. postizanju efikasnosti intelektualnog potencijala i poticanju mentalne kondicije;

10. prepoznatljivosti značaja pedagoške struke i njezina sustava vrijednosti;

11. ostvarenju/oživotvorenju društveno odgovorne pedagogije, znači odgojno-obrazovnih procesa.

Obrazovne aktivnosti s takvim ciljevima is ranije generalno naznačenim sadržajima bile bi namijenjene sljedećim organizacijama, strukturama i pojedincima:

1. asistentima i profesorima nastavničkih i nenastavničkih fakulteta;

2. ravnateljima svih razina državnih obrazovnih institucija (osnovnih škola, gimnazija, srednjih strukovnih škola (obrazovno usavršavanje);

3. nastavnicima pojedinih predmeta u osnovnim i srednjim školama - javnim i privatnim (dopunsko pedagoško-psihološko obrazovanje), pitanje licence kao u Velikoj Britaniji;

4. ravnateljima privatnih osnovnih i srednjih škola (obrazovno usavršavanje);

5. djelatnicima i ravnateljima u vrtićima - javnim (državnim) i privatnim (dopunsko pedagoško-psihološko obrazovanje);

6. zaposlenicima različitih kategorija u prosvjetnim ustanovama (agencije, ministarstva, sveučilišne strukture) - (obrazovno usavršavanje);

7. savjetnicima, mentorima, stručnim suradnicima (obrazovno usavršavanje);

8. zaposlenicima privatnih (vele)učilišta i sveučilišta (obrazovno usavršavanje);

9. zaposlenicima u gospodarstvenim institucijama javnim i privatnim, koje se bave managementom i obrazovanjem, a za to nemaju odgovarajuću kvalifikaciju (obrazovno usavršavanje).

Na osnovi brojne obrazovne populacije koja proizlazi iz rečenog očekivani rezultati podrazumijevali bi:

1. bolje spoznavanje i razvijanje posla kojim se bave sve stručne, a posebno nestručne osobe;

2. postizanje većeg digniteta i prepoznatljivosti pedagoške struke i pedagogijske znanosti u funkciji razvoja ostalih profesija; 
3. razvoj svijesti da je pedagogija kao odgojno-obrazovna znanost i djelatnost svugdje oko nas te da je treba koristiti u svim segmentima života;

4. usvajanje viših kriterija i kvalitetnijeg sustava vrijednosti (u poslu/obitelji/društvu/nastavi - posebice sveučilišnoj);

5. prepoznavanje potrebe za ostvarenjem cjeloživotnog obrazovanja.

Potraga za znanjem pustolovna je strategija - za one koji to znaju cijeniti. Jer znanje je bogatstvo, ono je razvojni kapital sredine i pojedinaca koji su osvijestili svoje vlastite kvalitete i potencijale te obrazovne vrijednosti. Društvena je odgovornost nacionalna odgovornost temeljena na ekonomskim i obrazovnim vrijednostima i one čine stratešku dimenziju ostvarivanja konkurentnosti. Pitanje je kako to postići. Međunarodna iskustva, zatim sustavno ulaganje u profesionalno usavršavanje i dodatno obrazovanje nastavnika - činitelji su strateškog upravljanja svim obrazovnim razinama kao i ljudskim resursima. To su pretpostavke za obogaćivanje ljudskog kapitala i njegovu infiltraciju u razvojne pore društva. Svim procesima, svim funkcijama, svim segmentima društva temeljna je komponenta čovjek. Kakav? Educiran, prosvijetljen, kreativan, kritičan... No sve to, $i$ još više, postaje se osobnim angažmanom, učenjem, radom - uz pretpostavku postojanja socijalnog i institucionalnog senzibiliteta za napredak. 


\section{Literatura:}

Afrić, V. i dr. (2011.) ur., Društvene pretpostavke društva znanja, Zagreb: Filozofski fakultet Sveučilišta u Zagrebu, Institut društvenih znanosti Ivo Pilar, Učiteljski fakultet Sveučilišta u Zagrebu.

Deklaracija o znanju - Hrvatska temeljena na znanju i primjeni znanja (2004.), Zagreb: Hrvatska akademija znanosti i umjetnosti.

Europe 2020, A Strategy for Smart, Sustainable and Inclusive Growth (2010.), Brussels: European Comission.

Keely, B. (2009.), Ljudski kapital (Od predškolskog odgoja do cjeloživotnog učenja), Zagreb: Educa.

Liessman, K.P. (2009.), Teorija neobrazovanosti, zablude društva znanja, Zagreb: Jesenski i Turk.

Marinković, R., Karajić, N. (2004.) ed. Future and the Role of Teachers, Zagreb: Faculty of Science University of Zagreb.

Marinković, R. (2007.) ed., New Perspectives in Quality Development of Higher Education, Zagreb: A.Z.P. Grafis d.o.o.

Marinković, R.: (2007.), ed. Quality Management and Communication in Higher Education, Zagreb: A.Z.P. Grafis d.o.o.

Reinalda, B., Kulescza, E. (2005.), The Bologna Process - Harmonizing Europe's Higher Education, Barbara Budrich Publishers, Opladen \& Bloomfield Hills.

Rethinking Education: Investing in Skills for Better Socio-Economic outcomes (2012.), Brussels /Strasbourg: European Comission.

Standards and Guidelines for Quality Assurance in the European Higher Education Area, (2007.), Helsinki: European Association for Quality Assurance in Higher Education.

TUNING : Tuning Educational Structures in Europe (Final Report) 


\section{Summary}

\section{Vino Amaro of Our Social System - Effects of the Educational and Scientific Policies}

The introductory part of this paper observes/considers the state of affairs of the present educational system in the current socialist conditions, both national and foreign ones. Simultaneously the issue is being treated of our unreadiness (at all possible levels) regarding the impact of foreign „interested parties". A specific interest is linked to the possible innovation of university teaching accompanied by the quality active engagement of university professors as well of students. Research issue are concretized via interdisciplinary and international access and orientation. The principle of interactivity between the professors and the students in higher education is the issue of guarantee of quality performance and correct promotion of the significance of intellectualness. A particular weight is attached to the systematism of professional development and university staff enhancement as well as the adecquate impact on social, mental and emotional competence of the students. What arises from this is the indication of the need for a more intensive development of university higher education of professors - assistants and student via programming, organizational, communicational and other manners of activity. In terms of methodology, the cognitions are supported by indicators of foreign and domestic research as well as a comparative analysis of data whose results show the exact factual situation in higher education. On the basis of such indicators obvious implications can be defined, uncontrollably included into the practice of university teaching and its results.

Keywords: higher education; interactivity; interdisciplinarity; international experience; professional development; university teaching. 
